\title{
Simultaneous Detection of the Defoliating and Nondefoliating Verticillium dahliae Pathotypes in Infected Olive Plants by Duplex, Nested Polymerase Chain Reaction
}

J. Mercado-Blanco, D. Rodríguez-Jurado and S. Parrilla-Araujo, Instituto de Agricultura Sostenible (IAS), Consejo Superior de Investigaciones Científicas (CSIC), Apdo. 4084, 14080 Córdoba, Spain; and R. M. JiménezDíaz, IAS-CSIC, and Escuela Técnica Superior de Ingenieros Agrónomos y Montes, Universidad de Córdoba, Apdo. 3048, 14080 Córdoba, Spain

\begin{abstract}
Mercado-Blanco, J., Rodríguez-Jurado, D., Parrilla-Araujo, S., and Jiménez-Díaz, R. M. 2003. Simultaneous detection of the defoliating and nondefoliating Verticillium dahliae pathotypes in infected olive plants by duplex, nested polymerase chain reaction. Plant Dis. 87:1487-1494.

Pathogen-free certified planting material and accurate detection of Verticillium dahliae pathotypes infecting the plant are key components of successful management of Verticillium wilt of olive. Use of a nested-polymerase chain reaction (PCR) procedure developed in earlier studies for in planta detection of the defoliating (D) and nondefoliating (ND) $V$. dahliae pathotypes resulted in ambiguous detection of the pathogen in some cases, due to heterologous amplification of the D-associated marker in ND-infected olive plants. In the present study, an improved procedure was developed that eliminates ambiguity and reduces time and cost for detection of $\mathrm{D}$ and ND $V$. dahliae in olive. The improved procedure is based on the simultaneous amplification of both an ND- and a new D-specific marker by means of duplex, nested PCR. The procedure was effective in the rapid and unequivocal detection of the D and ND V. dahliae in both artificially inoculated, own-rooted olive plants and naturally infected adult olive trees of different cultivar, age, and growing conditions. Furthermore, the duplex, nested-PCR procedure detected simultaneously the D and ND pathotypes in adult olive trees naturally infected by both pathotypes and in young olive plants that were double-inoculated with D and ND isolates under controlled conditions.
\end{abstract}

Additional keywords: Olea europaea

Verticillium wilt, caused by Verticillium dahliae Kleb., is one of the most serious diseases affecting olive (Olea europaea L.) worldwide (10) and may cause severe losses and plant death $(1,32)$. In Spain, the disease was first reported in 1980 (5); however, during the last 20 years it has spread throughout the main olive-growing areas of Andalucia, in southern Spain, as well as other regions in the country $(4,26$; R. M. Jiménez-Díaz, unpublished data). Several factors might account for the increasing spread of the disease, including use of infected planting material, establishment of new orchards in infested soils or close to affected crops, and establishment of irrigated orchards with a high tree density.

Severity of attacks by $V$. dahliae depends upon virulence (i.e., the amount of disease caused in a host genotype) of the

Corresponding author: R. M. Jiménez-Díaz E-mail: ag1jidir@uco.es

Research support was provided by the European Commission (Framework Programme 5; project reference number QLRT-1999-1523).

Accepted for publication 27 July 2003.

Publication no. D-2003-1007-04R

(C) 2003 The American Phytopathological Society pathogen isolates. $V$. dahliae isolates infecting olive can be classified into defoliating (D) and nondefoliating (ND) pathotypes, based on their ability to cause defoliation or no defoliation of green leaves from shoots and twigs $(24,25)$. Differential virulence of $V$. dahliae isolates also occurs in upland cotton (Gossypium hirsutum L.), and isolates from cotton and olive show cross-virulence in olive plants $(25,27,29)$. Infections by the D pathotype can be lethal to the plant, but olive plants infected by the ND pathotype can show complete remission from symptoms $(10,24)$. Although the D pathotype was first reported in Spain in an area of intensive cotton cultivation (2), it has spread to distant olive-growing areas and now causes severe Verticillium wilt in newly established, intensively managed olive orchards (3,18; R. M. Jiménez-Díaz, unpublished data).

The rapid and consistent detection of $V$. dahliae pathotypes infecting olive plants, particularly the D pathotype, is of importance for the management of Verticillium wilt. Early detection would help to avoid spread of the pathogen to new areas, especially if they are free from the highly virulent $\mathrm{D}$ pathotype. In previous studies, we developed a molecular procedure for the early and differential detection of the D and ND $V$. dahliae pathotypes in sympto- matic and nonsymptomatic but infected olive plants $(14,15)$. This procedure included extraction of polymerase chain reaction (PCR)-quality DNA of $V$. dahliae and use of pathotype-specific primers in a nested-PCR protocol. However, we found that the DNA sequence identifying D isolates also is present, though with a nucleotide shift, in some ND isolates of $V$. dahliae. This leads to the possibility that heterologous DNA amplification may occur when using the nested-PCR protocol for detection of the $\mathrm{D}$ pathotype (15). Therefore, the accurate detection of $\mathrm{D}$ and ND pathotypes in infected olive tissues requires that two independent, nested-PCR assays (one for each pathotype) are run in parallel. Other primers designed to differentiate among Verticillium spp. $(6,12,16,19)$ have been used successfully for in planta detection and quantification of the pathogen $(7-9,17,23)$. However, the differentiation of D and ND $V$. dahliae pathotypes was not tested in those studies. The objectives of the present study were to (i) improve the reliability of detection of $\mathrm{D}$ and ND $V$. dahliae pathotypes in infected olive trees by using a set of primers in a duplex, nested-PCR procedure that also would assure detection of the pathogen species; and (ii) demonstrate that the improved procedure would detect the two pathotypes in co-infected olive plants.

\section{MATERIALS AND METHODS}

Chemicals, fungal isolates, and culture media and conditions. Reagents used in this study were from Sigma-Aldrich, St. Louis; Merck, Darmstadt, Germany; or Panreac, Barcelona, Spain, unless otherwise indicated. Media were made with deionized water and autoclaved at $121^{\circ} \mathrm{C}$ for $20 \mathrm{~min}$. Potato-dextrose agar (PDA) and potato-dextrose broth (PDB) were from Difco Laboratories, Detroit.

For artificial inoculation of olive plants, V. dahliae isolates V4I and V138I, representative of the ND and D pathotypes, respectively, were used. These isolates were characterized in previous studies $(2,20,25)$ and are deposited in the culture collection of the Departamento de Protección de Cultivos, Instituto de Agricultura Sostenible, Córdoba, Spain. In addition, a number of different $V$. dahliae (D and ND) isolates also were used for the specific purpose of validating the PCR protocols 
developed in this study. All of these latter isolates also are deposited in the abovementioned culture collection. Isolates were stored by covering cultures on plum-extract agar (30) with liquid paraffin (2) at $4^{\circ} \mathrm{C}$ in the dark. Active cultures of isolates were obtained on water agar amended with chlorotetracycline (CWA) at $30 \mathrm{mg} \mathrm{liter}^{-1}$ and further subculturing on PDA. Cultures on PDA were grown for 7 days at $24^{\circ} \mathrm{C}$ in the dark.

Fungal and plant DNA extraction. Mycelia of $V$. dahliae isolates were obtained from cultures in PDB, lyophilized, and ground to a fine powder using an autoclaved pestle and mortar as previously described (20). Powdered mycelia (50 mg) was used for DNA extraction (21). The DNA thus obtained served as controls in the PCR reactions described below. Total genomic DNA was extracted from shoots and roots of naturally infected olive trees, as well as artificially infected and noninfected, own-rooted olive plants using the DNeasy Plant Mini Kit (Qiagen, Hilden, Germany; 14). Suitability of total genomic DNA from olive tissues for PCR was verified by PCR assays using primer pair IASoli17f/r (22). This primer pair defines a microsatellite marker in olive of about 190 bp that should be amplified in DNA samples of PCR quality. Amplification reactions $(25 \mu \mathrm{l})$ were done as indicated below except that primers were added to a final concentration of $0.2 \mu \mathrm{M}$ each. Reaction conditions were denaturation at $94^{\circ} \mathrm{C}$ for 4 min, followed by 35 cycles of $1 \mathrm{~min}$ of annealing at $64^{\circ} \mathrm{C}$, extension for $1 \mathrm{~min}$ at $72^{\circ} \mathrm{C}$, denaturation for $1 \mathrm{~min}$ at $94^{\circ} \mathrm{C}$, and a final extension step of $6 \mathrm{~min}$.

Design of a new primer for PCRbased identification of $V$. dahliae $\mathrm{D}$ pathotype. Carder and co-workers (6) reported that primer pair DB19/DB22 yields a $V$. dahliae-specific product in PCR assays. We tested this primer pair for the identification of $V$. dahliae $\mathrm{D}$ isolates from cotton (V138I, V177I, and V180I) and olive (V135I, V136I, and V153I) and V. dahliae ND isolates from cotton (V176I, V213I, and V217I) and olive (V143I, V144I, and V152I) $(2,20)$, and found that $\mathrm{D}$ and ND isolates yielded polymorphic 530- and 540-bp bands of the species-specific marker, respectively. Those DNA bands were sequenced and a new primer was designed for a PCR strategy of pathotype identification using three primers in a single reaction. Amplifications using DB19/DB22 primers were carried out as indicated below except that primers were added at $0.4 \mu \mathrm{M}$ each, annealing temperature was set at $58^{\circ} \mathrm{C}$, and 30 cycles were run. The 540- or 530-bp PCR products then were purified by the QIAquick PCR purification kit (Qiagen), according to the manufacturer's instructions. DNA sequencing of the purified PCR products was carried out using the forward primer DB19, and the DNA sequences were determined using an Applied Biosystems Model 310 automated DNA sequencer. All primers used in this study were obtained from Genset Oligos, Genset SA, Paris, France. The sequences obtained were deposited in the EMBL/GenBank/DDBJ nucleotide sequence databases under the following accession numbers: AF481966 (isolate V136I), AF481967 (V138I), AF481968 (V135I), AF481969 (V143I), AF481970 (V152I), AF481971 (V144I), AF481972 (V153I), AF481973 (V180I), AF481974 (V213I), AF481975 (V177I), AF481976 (V217I), and AF481977 (V176I). After the resulting sequences were compared, the reverse primer espdef01 (5'-TGAGACTCGGCTGCCACAC-3') was designed. Different ratios of primers DB19, DB22, and espdef01 concentration, number of cycles, and annealing temperatures were tested to optimize differentiating between $\mathrm{D}$ and ND $V$. dahliae pathotypes using the three primers in a single reaction. The annealing temperature was finally set at $62^{\circ} \mathrm{C}$, according to the melting temperatures of the three primers DB19 at $58^{\circ} \mathrm{C}, \mathrm{DB} 22$ at $60^{\circ} \mathrm{C}$, and espedef01 at $62^{\circ} \mathrm{C}$; and 35 cycles produced consistent results. The final, appropriate micromolar ratio of primers was empirically set at 1:7:2 for the reverse primer DB22, the forward primer DB19, and the internal reverse primer espdef01, respectively. Amplification reactions $(25 \mu \mathrm{l})$ consisted of a micromolar ratio of 1:7:2 (DB22:DB19: espdef01) of primers, $200 \mu \mathrm{M}$ each dNTP, $2.5 \mu \mathrm{l}$ of $10 \times$ reaction buffer $(166 \mathrm{mM}$ $\left[\mathrm{NH}_{4}\right]_{2} \mathrm{SO}_{4}, 670 \mathrm{mM}$ Tris-HCl, pH 8.8 $\left[25^{\circ} \mathrm{C}\right], \quad 0.1 \%$ Tween-20), $0.75 \mathrm{U}$ of EcoTaq (Ecogen S.R.L., Barcelona, Spain), $1.5 \mathrm{mM} \mathrm{MgCl}_{2}$, and $10 \mathrm{ng}$ of template DNA. Reaction conditions included denaturation at $94^{\circ} \mathrm{C}$ for $4 \mathrm{~min}$ followed by 35 cycles of $1 \mathrm{~min}$ of annealing at $62^{\circ} \mathrm{C}$, extension for $30 \mathrm{~s}$ at $72^{\circ} \mathrm{C}$, denaturation for $1 \mathrm{~min}$ at $94^{\circ} \mathrm{C}$, and a final extension step of $6 \mathrm{~min}$.

In planta detection of the D and ND $V$. dahliae pathotypes by duplex, nested PCR. Three different sets of total genomic DNA were used.

One set of stored DNA samples originated from nursery-propagated, ownrooted olive cv. Picual plants that were artificially inoculated with the D or ND $V$. dahliae pathotypes in previous studies $(14,15)$. These samples were used in this study to optimize a duplex, nested-PCR procedure for in planta detection of $V$. dahliae pathotypes. The samples of total genomic DNA (20 ng) were extracted from roots of inoculated and noninoculated plants sampled at time 0 (just after dipping roots in water or in a conidial suspension), and at 7 and 52 days after inoculation $(14,15)$.

A second set of samples of total genomic DNA originated from an inoculation experiment that was carried out in this study to demonstrate co-infection of olive plants by $\mathrm{D}$ and ND of $V$. dahliae. A total of 50 nursery-propagated, own-rooted, 7-monthold olive cv. Arbequina plants were used. Plants were root-dip inoculated in a suspension of $10^{7}$ conidia $\mathrm{ml}^{-1}$ of the pathogen for $1 \mathrm{~h}(14,15)$. Conidia were obtained by flooding 7-day-old cultures on PDA and filtering the suspension through sterile cheesecloth. A group of 10 plants were separately inoculated with isolates V138I (D) or V4I (ND). Additionally, 15 plants were co-inoculated by first dipping the roots of a plant in a conidial suspension of the ND isolate V4I for $1 \mathrm{~h}$, then in a different container for an additional hour in a conidial suspension of the D isolate V138I. Fifteen plants, similarly treated except for the absence of inoculum, served as uninoculated controls. The experiment was arranged as a completely randomized design. After inoculation, plants were transplanted into sterile soil (sand:loam, $2: 1, \mathrm{vol} / \mathrm{vol}$ ) in pots and incubated at light and dark temperatures of 22 and $24^{\circ} \mathrm{C}$, respectively, with a 14-h photoperiod of fluorescent light of $262 \mu \mathrm{E} \mathrm{m} \mathrm{m}^{-2} \mathrm{~s}^{-1}$. Plants were watered with a hydro-sol fertilizer (20-5-32 + microelements; Haifa Chemicals, Ltd, Haifa, Israel) every week. Plants were observed for the development of symptoms at 4-day intervals after inoculation. Double-inoculated and uninoculated plants were sampled (three plants per time interval) at 7, 14, 21, and 85 days after inoculation. In addition, three V138I-inoculated and three V4I-inoculated plants were sampled 21 and 85 days after inoculation. Stem and root tissues from sampled plants were processed separately, as mentioned above, and used for extraction of total genomic DNA. Samples of 20 ng DNA were used as templates in PCR assays.

A third set of samples of total genomic DNA originated from Verticillium wiltaffected olive trees sampled in commercial orchards. These trees were selected as representative of different tree ages, cultivars, and geographic origin (Table 1), and used to validate the diagnostic procedure. Total genomic DNA was extracted from branches, twigs, and occasionally from fallen green leaves of affected plants. Tissues were thoroughly washed, surface disinfested in $\mathrm{NaClO}(0.5 \%$ available chlorine) for $2 \mathrm{~min}$, freeze dried, and ground to a fine powder (15) for subsequent DNA extraction. Infection of sampled tissues by $V$. dahliae also was determined by isolation of the fungus on CWA. For each sample, arbitrarily selected, 5-mm-long pieces of stems and leaves were surface disinfested as above, plated onto CWA, and incubated at $24^{\circ} \mathrm{C}$ in the dark for at least 9 days (25). DNA extracted from mycelia developed on CWA was used to further confirm pathotype identification using the three-primer PCR protocol developed in the study.

Duplex, nested-PCR assays were carried out for the joint, simultaneous detection of $\mathrm{D}$ and ND $V$. dahliae pathotypes. Primer pairs DB19/DB22 and NDf/NDr were used 
in the first round of amplification. The use of primer pair DB19/DB22 yielded a PCR product of 540 or $530 \mathrm{bp}$, which is a marker for $V$. dahliae (6), and that of NDf/NDr yielded a product of 1,410 bp, which is specific for ND V. dahliae (14). Amplification reactions $(25 \mu \mathrm{l})$ in this round consisted of $0.4 \mu \mathrm{M}$ each primer, $200 \mu \mathrm{M}$ each dNTP, $2.5 \mu \mathrm{l}$ of $10 \times$ reaction buffer, $0.75 \mathrm{U}$ of EcoTaq, $2.5 \mathrm{mM} \mathrm{MgCl}$, and $20 \mathrm{ng}$ of template DNA. Reaction conditions were denaturation at $94^{\circ} \mathrm{C}$ for 4 min followed by 30 cycles of $1 \mathrm{~min}$ of annealing at $58^{\circ} \mathrm{C}$, extension for $1 \mathrm{~min}$ at $72^{\circ} \mathrm{C}$, denaturation for $1 \mathrm{~min}$ at $94^{\circ} \mathrm{C}$, and a final extension step of $6 \mathrm{~min}$.

The second round of amplification was carried out using the nested primer pairs INTND2f/INTND2r and DB19/espdef01. Primer pair INTND2f/INTND2r yielded a 824-bp PCR product, which is specific for ND $V$. dahliae (14), and primer pair DB19/espdef01 yielded a 330-bp PCR product, which is specific for $\mathrm{D} V$. dahliae. For nested PCR, $0.5 \mu \mathrm{l}$ of the product from the first round of amplification was transferred to a fresh tube containing the mixture for the second amplification reaction. Conditions and parameters used in this round of amplification were the same as for the first round, except that only 25 cycles were run with the annealing temperature set at $62^{\circ} \mathrm{C}$ for $30 \mathrm{~s}$, and the final extension step was $10 \mathrm{~min}$.

All PCR assays in this work were performed with a PTC-100 Programmable
Thermal Controller (MJ Research, Inc., Watertown, MA). Amplification products were separated on $1 \%$ agarose gels, stained with ethidium bromide, and visualized under UV light. The DNA size markers used for electrophoresis were from Boehringer-Mannheim. Reactions were repeated at least three times and always included negative controls (no DNA) and positive controls (template DNA from $V$. dahliae isolates representative of the $\mathrm{D}$ and ND pathotypes, purified from mycelia grown in culture).

\section{RESULTS}

A new marker for the identification of D $V$. dahliae. The two PCR products amplified by primer DB19/DB22 from D and ND $V$. dahliae differed by 16 bp (i.e., $523 \mathrm{bp}$ for the ND isolates and $539 \mathrm{bp}$ for the $\mathrm{D}$ isolates). The 539-bp sequence amplified from D isolates harbored a 15nucleotide (nt) insertion (5'-CGTGTGGCAGCCGAG-3') between nucleotide positions 313 and 314 of the consensus sequence of the ND isolates, and one 1-nt insertion (an extra C) between nucleotide positions 163 and 164 . These additional 16 bp were absent from all ND isolates sequenced.

The 15-nt insertion present only in $\mathrm{D} V$. dahliae was the basis for designing a new PCR primer, the reverse primer defesp01 (located at nucleotide positions 315 to 333 of the amplicon produced byDB19/DB22 from $\mathrm{D}$ isolates), specific for the $\mathrm{D}$ patho- type. This primer, used in combination with the forward primer DB19, yielded a 334-bp PCR product from D $V$. dahliae DNA as template when screening a large number of D $V$. dahliae isolates $(2,20)$ from our culture collection (data not shown). Also, the combined use of primers DB19, DB22, and espdef01 allowed differentiation between $\mathrm{D}$ and ND $V$. dahliae pathotypes in a single PCR assay (Fig. 1). The ratio of primer concentration was the most important parameter to optimize results in this assay. An equal molar ratio for the three primers yielded the predicted 334-bp band for D isolates; however, the 523-bp, V. dahliae species-specific band was amplified by neither ND nor D isolates (Fig. 1B). Increasing concentrations of the DB19 forward primer produced the predicted amplicons of 539 and 334 bp from $\mathrm{D}$ isolates and the single amplicon of $523 \mathrm{bp}$ from ND isolates. However, other ratios of primer concentration (for example, 1:7:1 and 1:3:1) also produced the predicted results (Fig. 1B). The use of this three-primer PCR strategy for the simultaneous identification of $V$. dahliae and characterization of $\mathrm{D}$ and ND pathotypes in a single-PCR assay finally was tested employing our Verticillium culture collection. In all cases, the predicted diagnostic bands were produced. An example of this testing is presented in Figure 2.

Optimization of a duplex, nested-PCR procedure for in planta detection of $V$. dahliae pathotypes. The joint use of the $V$.

Table 1. Detection of defoliating (D) and nondefoliating (ND) Verticillium dahliae pathotypes in naturally infected olive plants of diverse cultivar, age, and geographic origin by duplex, nested-polymerase chain reaction (PCR)

\begin{tabular}{|c|c|c|c|c|c|c|c|}
\hline Geographic origin & Cultivar & $\begin{array}{c}\text { Sampled tissue } \\
\text { (no. of trees assayed) }^{\mathrm{a}}\end{array}$ & $\begin{array}{l}\text { Tree age } \\
(\text { years })^{b}\end{array}$ & $\mathbf{P C R}^{\mathrm{c}}$ & $\begin{array}{c}\text { Pathotype and } \\
\text { no. of positive } \\
\text { detections }^{\mathrm{d}}\end{array}$ & $\begin{array}{c}\text { Joint detection } \\
\text { of D and ND } \\
\text { pathotypes }\end{array}$ & $\begin{array}{l}\text { Positive } \\
\text { isolation on } \\
\text { CWA }\end{array}$ \\
\hline \multicolumn{8}{|l|}{ Southern Spain } \\
\hline \multirow{3}{*}{ CIFA, Córdoba } & Arbequina & Wilted branches (45) & $4-5$ & 25 & D 25, ND 2 & Yes (2) & 13 \\
\hline & $\ldots$ & Green branches (45) & $\ldots$ & 26 & D 24, ND 10 & Yes $(8)$ & 26 \\
\hline & $\ldots$ & Green leaves (2) & $\ldots$ & 2 & D 2 & No & 2 \\
\hline \multicolumn{8}{|l|}{ Córdoba province } \\
\hline Fuente Palmera & Arbequina & Green branches (2) and leaves (1) & 3 & 2,1 & D 3 & No & 3 \\
\hline \multirow{3}{*}{ Posadas } & Manzanilla & Green branches (2) & NA & 2 & D 2 & No & 2 \\
\hline & Picual & Wilted branches (6) & 8 & 1 & D 1 & No & 0 \\
\hline & $\ldots$ & Green branches (6) & $\ldots$ & 4 & D 4 & No & 2 \\
\hline \multicolumn{8}{|l|}{ Seville province } \\
\hline Osuna & Arbequina & Green branches (6) & 3 & 3 & D $3, \mathrm{ND} 3$ & Yes (3) & 3 \\
\hline Granada & Unknown & Green branches (3) & $>25$ & 2 & D 2 & No & 0 \\
\hline \multicolumn{8}{|l|}{ Northeastern Spain } \\
\hline Huesca & Arbequina & Green branches (5) & 3 & 2 & ND 2 & No & 0 \\
\hline \multicolumn{8}{|l|}{ Central-eastern Spain } \\
\hline Valencia $^{\mathrm{f}}$ & 21 cultivars & Green branches (25) and roots (25) & NA & 0 & Negative & No & Not det.g \\
\hline Argentina & Three cultivars ${ }^{\mathrm{h}}$ & Green branches (4) & 9 & 0 & Negative & No & 0 \\
\hline
\end{tabular}

${ }^{a}$ Wilted branches: tissue samples from branches of olive trees with a range of symptoms severity, from severe wilting of still-green branches to necrotic branches. Green branches: tissue samples from affected olive trees that included green twigs and branches.

${ }^{\mathrm{b}} \mathrm{NA}$ : information was not available.

${ }^{c}$ Total number of positive amplifications. All samples positive for $V$. dahliae by isolation on chlorotetracycline (CWA) also were positive by PCR assay.

${ }^{d}$ D: presence of the D-specific marker (approximately 330-bp amplicon); ND: presence of the ND-specific marker (824-bp amplicon).

${ }^{\mathrm{e}}$ Simultaneous detection of both D- and ND-specific markers in template DNA extracted from an infected tissue sample. In parentheses, the number of tissue samples where both amplicons were detected.

${ }^{\mathrm{f}}$ Samples were supplied by COTEVISA commercial nursery at Valencia, Spain. They were pruned from stock plants used for propagation routinely. These stock plants had been indexed for V. dahliae by isolation and were considered as $V$. dahliae-free plants and used as reference and negative controls for $V$. dahliae-PCR detection in this study. Cultivars represented were: Arbequina, Ascolana tenera, Blanqueta, Chemlali, Cordobil, Cornezuelo, Cornicabra, Coroneiqui, Dolça, Gordal, Grossal, Hojiblanca, Manzanilla, Morrut, Oblonga, Ocal, O-577, Picual, Sevillenca, Tomas, and Villalonga.

g Not determined.

h Samples were from cvs. Manzanilla, Nabali, and Picual. 
dahliae species-specific primer pair DB19/DB22 and the ND $V$. dahliae-specific primer pair NDf/NDr in a single PCR assay should simultaneously identify $V$. dahliae as well as D and ND pathotypes in a test sample of genomic DNA. A duplexPCR assay using the two above primer pairs and DNA (10 ng) from mycelia of a sample of ND $V$. dahliae isolates produced two amplicons: a band of 1,410 bp (corresponding to the amplicon defined by primer pair NDf/NDr) and a band of 523 bp (specific for $V$. dahliae and defined by primer pair DB19/DB22) (data not shown). In contrast, a single amplicon of 539 bp was produced when DNA (10 ng) from mycelia of a sample of D isolates was used as template in a similar assay. The specific band for ND isolates was lacking in this latter assay. An example from a PCR assay using ND $V$. dahliae isolate V4I (lane ND) and D V. dahliae isolate V138I (lane D) is shown in Figure 3A. The sequence amplified by primer pair DB19/DB22 from $\mathrm{D}$ isolates contains 16 bp lacking in ND isolates; therefore, a second duplex-PCR assay employing an aliquot $(0.5 \mu \mathrm{l})$ of the first amplification and the corresponding pathotype-specific nested primers in the reaction mixture should yield the diagnostic D or ND-specific amplicon. Actually, the ND-specific 824-bp band defined by primer pair INTND2f/ INTND2r, and the D-specific 334-bp band defined by primer pair DB19/espedef01, were the only DNA bands produced employing mycelia of a sample of ND isolates (Fig. 3B, lane ND) or of D isolates (Fig. 3B, lane D), respectively. There were no heterologous amplification between $\mathrm{D}$ and ND pathotypes from the above assays.

Duplex, nested-PCR assays using total genomic DNA from roots of olive cv. Picual plants inoculated with D or ND $V$. dahliae amplified the band specific to the infecting pathotype. For plants inoculated with the D isolate V138I, the first duplexPCR reaction yielded only the 539-bp

A

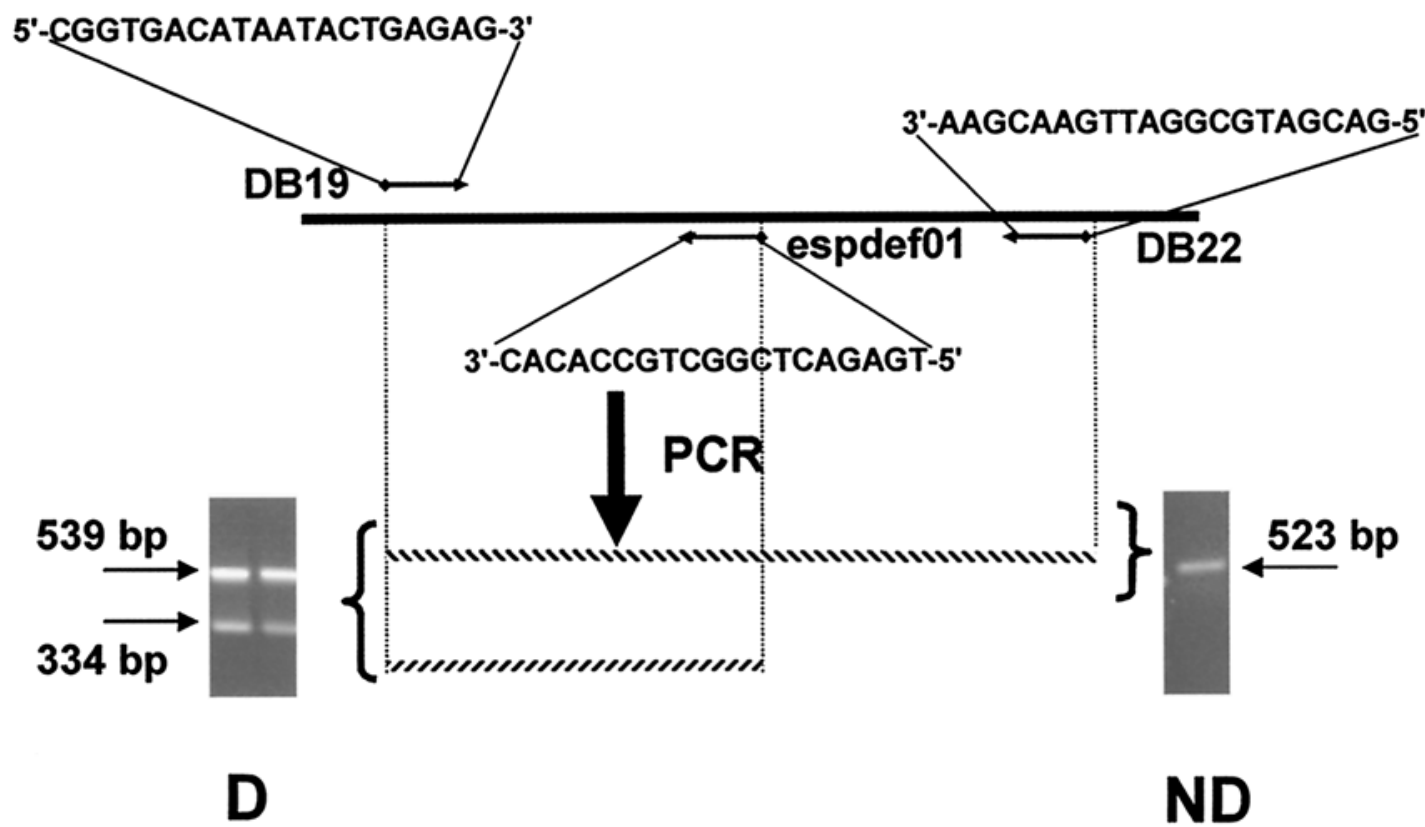

B

1:1:1
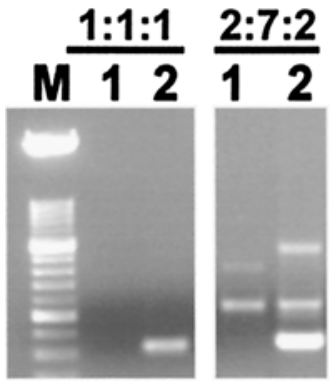

$\frac{1: 7: 2}{1: 2}$

$1: 3: 3 \quad 1: 3: 1$

$1: 7: 1$

$\frac{1: 7: 3}{12}$

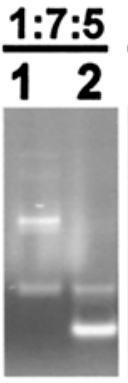

$\frac{1: 7: 7}{12}$
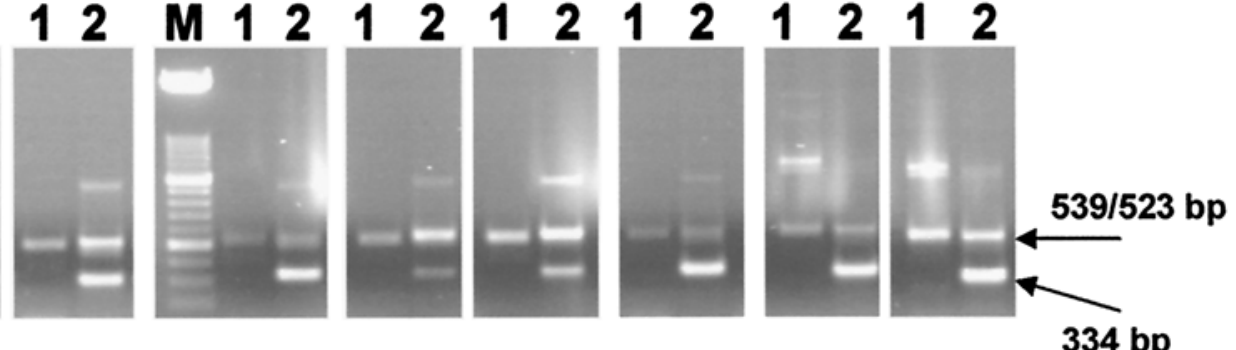

Fig. 1. A, Scheme depicting the strategy followed for the identification of Verticillium dahliae pathotype using template DNA from pure fungal culture, and polymerase chain reaction (PCR) products obtained when primers DB19, DB22, and espdef01 were used in a single-PCR reaction. A characteristic electrophoretic pattern of $V$. dahliae defoliating (D) pathotype showed two amplicons of $539 \mathrm{bp}$ (DB19/DB22) and 334 bp (DB19/espdef01). In contrast, DNA template from $V$. dahliae nondefoliating (ND) pathotype amplified only the 523 bp amplicon (DB19/DB22). B, PCR products amplified using different ratios of concentration of primers DB22:DB19:espdef01. M, Molecular weight marker; 1, lanes showing PCR products when ND V. dahliae V176I DNA was used as template; 2, lanes showing PCR products when D V. dahliae V138I DNA was used as template. 
amplicon. This DNA band was intense for roots sampled 7 days after inoculation (Fig. $3 \mathrm{~A}$, lanes 3 and 4 ) but faint for those sampled just after inoculation (Fig. 3A, lanes 1 and 2) or 52 days later (Fig. 3A, lanes 5 and 6). In contrast, plants inoculated with the ND isolate V4I yielded the two predicted amplicons of $1,410 \mathrm{bp}$ and 523 bp, which again were much more intense with DNA from roots sampled 7 days after the inoculation. To further assure specificity in the detection of D and ND pathotypes, we conducted a second round of duplex PCR (duplex, nested-PCR). The D-specific amplicon of 334 bp produced in a second round of amplification using DNA from roots of Picual olive plants inoculated with $\mathrm{D} V$. dahliae isolate V138I is shown in Figure 3. Likewise, the NDspecific amplicon of 824 bp was the only product using DNA from roots of plants inoculated with ND isolate V4I. Neither heterologous amplification nor amplification from uninoculated controls occurred in any of the experiments.

Co-infection of olive plants by $D$ and ND $V$. dahliae pathotypes. The joint infection by D and ND V. dahliae was demonstrated by duplex, nested-PCR assays using tissues of double-inoculated plants sampled 7, 14, 21, and 85 (data not shown) days after inoculation (Fig. 4). Olive plants inoculated with the D isolate yielded the D amplicon only, and those inoculated with the ND isolate yielded the ND amplicon only. Both amplicons were found only in olive plants inoculated with the D and ND isolates. Neither the D- nor ND-specific amplicons were produced using DNA samples from uninoculated controls. Results of the detection assay were influenced by the plant tissue sampled. Thus, although assays using root samples from inoculated plants amplified the diagnostic markers even after the first round of amplification (Fig. 4A), detection of the pathogen using stem samples from inoculated plants was possible after nested PCR only (Fig. 4C). The above assays revealed the presence of the pathogen in the stem of two of three Dinoculated plants and of one of three D/ND-double-inoculated plants sampled 21 days after inoculation. However, no detection was feasible in stems of NDinoculated plants at this sampling time. Interestingly, only the 334-bp D-specific marker was amplified in stems of doubleinoculated plants (Fig. 4C).

Detection of $V$. dahliae pathotypes in naturally infected olive trees in the field. Samples of total genomic DNA extracted from a wide variety of naturally infected adult olive trees were used to validate the duplex, nested-PCR procedure described above (Table 1). DNA extraction yielded a range of $150 \pm 45 \mathrm{ng}$ DNA/mg of freezedried tissue sample, which is in accordance with the amount of DNA extracted for stems of artificially infected, nurseryproduced young olive plants in previous studies (14). There were no significant differences in the amount of DNA extracted from olive trees of different cultivar and age. However, extraction from severely affected or necrotic twigs yielded much less DNA ( $44.5 \pm 21.5 \mathrm{ng}$ DNA/mg) than from twigs with mild symptoms of the disease. Furthermore, DNA from the necrotic tissue samples was of poor PCR quality in some instances, as indicated by lack of amplification of the microsatellite marker defined by primer pair Ias-17f/r (22) in PCR assays using this DNA as template (data not shown). Although the use of severely wilted olive tissue may confer difficulty for the detection procedure described, our results showed that molecular, in planta detection of $V$. dahliae pathotypes still was possible and provided improved results compared with the conventional microbiological procedure (Table 1). Thus, samples of stems from affected 'Arbequina' olive plants at CIFA Agricultural Experimental Station in Córdoba produced only 13 positive $V$. dahliae isolations on CWA out of 45 isolation attempts. In contrast, duplex, nested-PCR assays using same tissue yielded 25 positive determinations out of 45 assays which, in addition, were informative of the infecting pathotype. All trees positive for $V$. dahliae by isolations also were positive by PCR assays. Furthermore, the pathotypes identified in the nested-PCR assays were confirmed by three-primer PCR assays using DNA from mycelia growing on CWA. Similarly, improved results also were obtained using samples of adult olive

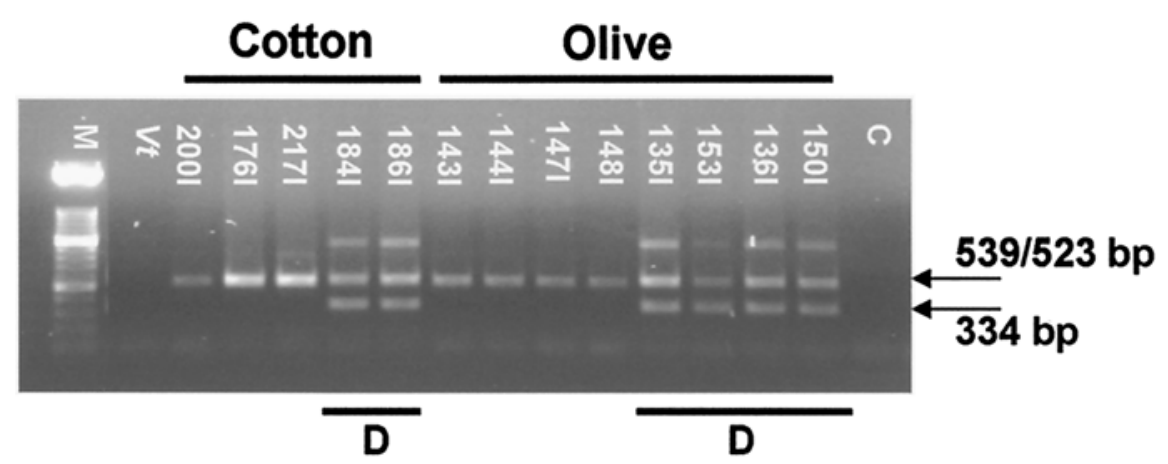

Fig. 2. Pathotyping of cotton and olive Verticillium dahliae isolates using the three-primer polymerase chain reaction protocol described in this study. Two negative control reactions were included: DNA from an isolate of $V$. tricorpus $(V t)$, and no template DNA (C). Bars with a D underneath the gel indicate $V$. dahliae isolates that were previously characterized as defoliating both by pathogenicity and molecular assays $(2,19)$.

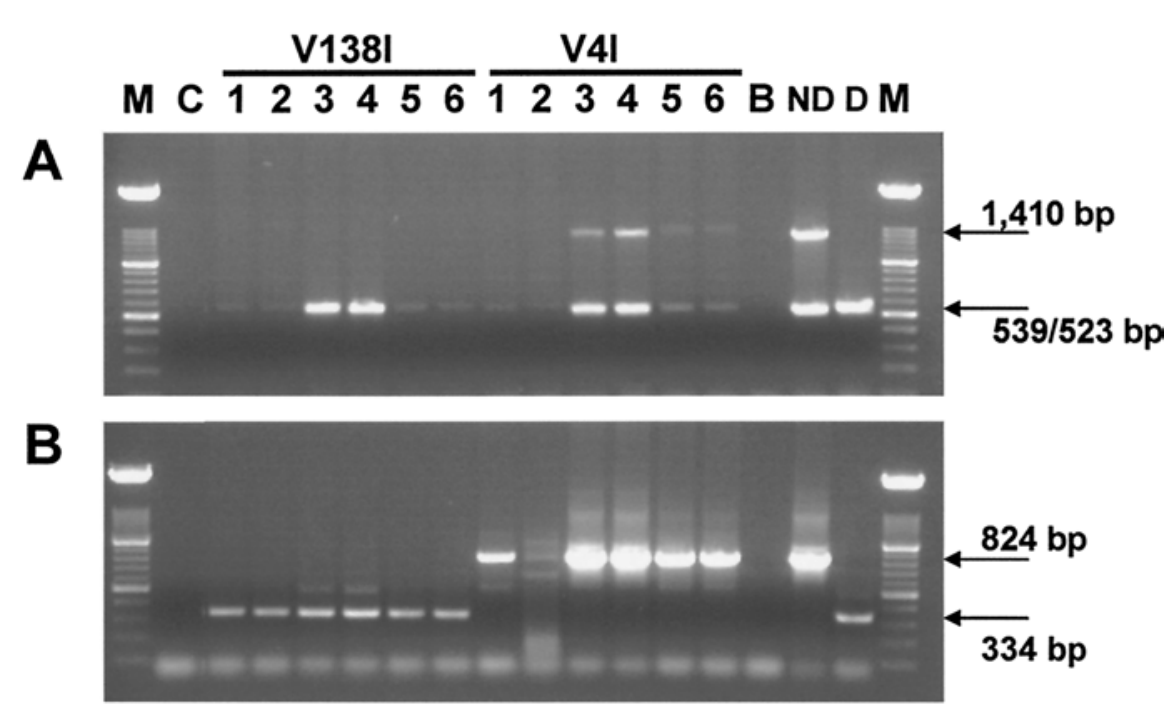

Fig. 3. Detection of Verticillium dahliae defoliating (D) isolate V138I and nondefoliating (ND) isolate V4I in samples of total genomic DNA extracted from roots of artificially infected, own-rooted Picual olive plants. Plants were inoculated by dipping the roots in a conidial suspension of the isolates. DNA from two plants sampled at 0 (just after inoculation; lanes 1 and 2), 7 days (lanes 3 and 4), and 52 days (lanes 5 and 6) after inoculation were submitted to the duplex, nestedpolymerase chain reaction (PCR) procedure described in this study. A, Results after the first round of amplification (using primer pairs NDf/NDr and DB19/DB22). B, Results after nested-PCR (using primer pairs INTND2f/INTND2r and DB19/espdef01). M, molecular weight marker; C, control reaction with DNA from uninoculated plant; B, negative PCR control reaction with no template DNA; ND, positive PCR control reaction with DNA of the ND V. dahliae V4I isolate; D, positive PCR control reaction with DNA of the D V. dahliae V138I isolate. 
trees from Posadas (Cordoba province) and Granada in southern Spain and from Huesca in northern Spain, using the molecular in planta-detection procedure compared with the conventional procedure. Both the D and ND V. dahliae pathotypes were singly detected in the assayed sam- ples, the D pathotype being the one detected most frequently in southern Spain. Conversely, only the ND pathotype was detected in samples from Huesca. Finally, assays using samples from olive orchards in Argentina and from pathogen-free, nursery-produced planting material of 21 olive

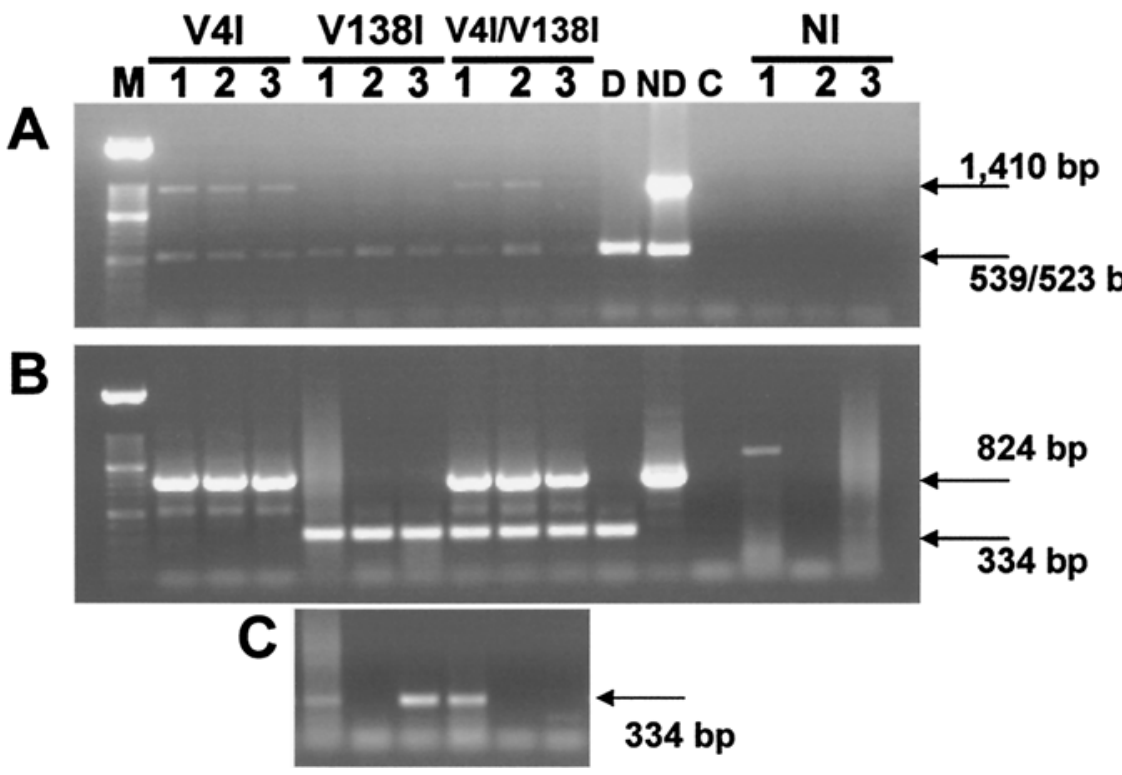

Fig. 4. Joint detection of defoliating (D) and nondefoliating (ND) Verticillium dahliae pathotypes in samples of total genomic DNA from roots and stems of artificially infected, own-rooted Arbequina olive plants that were co-inoculated with the ND isolate V4I and the D isolate V138I. Plants were sampled 21 days after inoculation. A, Results after the first round of amplification using DNA templates from roots. B, Results after nested-polymerase chain reaction (PCR) using $0.5 \mu \mathrm{l}$ of products from the first amplification reaction. C, Results after nested-PCR using DNA samples extracted from stems of the same plants for which results using DNA from roots are shown in $\mathbf{A}$ and $\mathbf{B}$. No results were obtained for V4I-inoculated and noninoculated plants. M, Molecular weight marker; 1, 2, and 3, three different plants sampled for each treatment; NI, noninoculated plants; C, negative control reaction with no template DNA; ND, positive PCR control reaction with DNA of the ND V. dahliae V4I isolate; D, positive PCR control reaction with DNA of the D V. dahliae V138I isolate.

\section{HUESCA OSUNA 2 $^{\text {nd }}$ PCR 1st PCR $^{\text {st }}$}

\section{$M 1234551234556$ NDDCND D C}

A
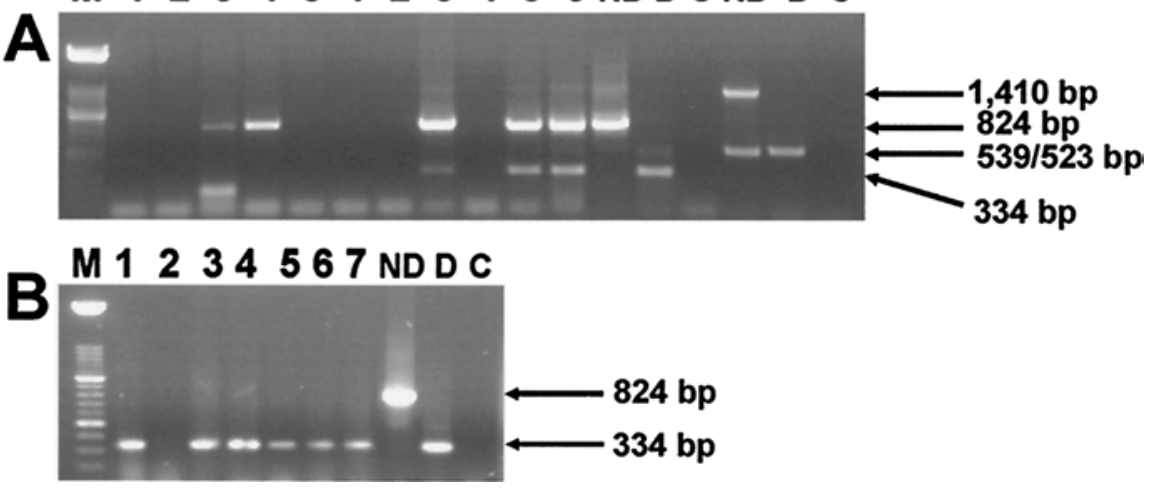

Fig. 5. A, Detection of Verticillium dahliae defoliating (D) and nondefoliating (ND) pathotypes in branches of naturally infected Arbequina olive trees from Huesca (northeastern Spain) and Osuna (southwestern Spain). Patterns of polymerase chain reaction (PCR) products after the nested-PCR amplification (second PCR) and first round of amplification (first PCR) using positive controls also are shown. B, Detection of D V. dahliae in samples of total genomic DNA from branches and leaves of naturally infected olive trees. Lanes 1 and 2, DNA from branches of Arbequina olives sampled at CIFA (Córdoba); lanes 3 and 4, DNA from branches of Manzanilla olives sampled at Fuente Palmera (Córdoba); lanes 5 and 6, DNA from leaves of Arbequina olives sampled at CIFA (Córdoba); lane 7, DNA from leaves of an Arbequina olive sampled at Fuente Palmera (Córdoba); C, negative PCR control reaction with no template DNA; ND, positive PCR control reaction with DNA of the ND $V$. dahliae V4I isolate; D, positive PCR control reaction with DNA of the D V. dahliae V138I isolate.

cultivars gave no positive detection of $V$. dahliae. These tissue samples served as appropriate negative controls in this study. In the above detection assays, an interesting result was the simultaneous production of the specific D (334-bp) and ND (824bp) amplicons in some individual samples of naturally infected olive trees (Table 1 , Fig. 5). In these cases, three-primer PCR assays of DNA from mycelia obtained in isolations also yielded the above D and ND amplicons. These results indicated that $\mathrm{D}$ and ND $V$. dahliae pathotypes can co-infect an olive tree under natural conditions.

\section{DISCUSSION}

Early, rapid, and reliable in planta detection of $V$. dahliae pathotypes can help to prevent pathogen-infected olive from being planted and thus facilitate the management of Verticillium wilt in olive (33). In previous studies, we designed specific primers and developed a nested-PCR procedure that allow detection of $\mathrm{D}$ and ND $V$. dahliae in symptomatic and nonsymptomatic nursery-propagated olive plants $(14,15)$. Because occasional heterologous amplification of the D-associated marker may occur when using total genomic DNA samples of ND-infected olive tissues, two independent nested-PCR assays run in parallel have been required to overcome any ambiguity for in planta diagnosis of pathotypes (15). The new duplex, nested-PCR procedure presented here eliminates the problem of heterologous DNA amplification, allows detection of co-infection by $\mathrm{D}$ and ND V. dahliae, and reduces the time and cost of diagnosis. The new procedure required designing a new specific primer (espdef01) and optimizing conditions for the nested-PCR assay. In addition, the combined use of primer espdef01 with primers DB19/DB22 (6) in a single-PCR assay proved valuable for the simultaneous identification of $V$. dahliae and characterization of D and ND pathotypes in Verticillium cultures. All D V. dahliae isolates screened so far produced a characteristic two-PCR-band pattern of 539 and 334 bp in size in agarose gels. Conversely, ND V. dahliae isolates yielded a PCR product of $523 \mathrm{bp}$, which is a species-specific marker of $V$. dahliae (6).

The improvement in the detection procedure includes the simultaneous in planta diagnosis of $\mathrm{D}$ and $\mathrm{ND} V$. dahliae based on the use of primer pairs NDf/NDr and DB19/DB22 in a first round of amplification and primer pairs INTND2f/ INTND2 $r$ and DB19/espdef01 in the second, nested round. The improved procedure was effective in the detection of $\mathrm{D}$ and ND $V$. dahliae in samples of total genomic DNA from own-rooted Picual olive plants that were single or double inoculated with the two pathoypes, and solved the problem of heterologous amplification that jeopardized detection of the D pathotype (15). Using this procedure, the 
new D marker of $334 \mathrm{bp}$ defined by primer pair DB19/espdef01 was never amplified from samples of ND-inoculated Picual olive plants.

In previous studies for in planta detection of D and ND V. dahliae, we used olive tissues from a time course sampling strategy after inoculation $(14,15)$. Here, to assess efficacy of the duplex, nested-PCR assay, we purposely used DNA samples stored from those studies that were extracted at time 0 (just after dipping roots in water or in a conidia suspension), 7 days (before expression of symptoms) and 52 days (after disease reached maximum symptoms severity) after inoculation $(14,15)$. With these DNA samples, we aimed to challenge the improved detection procedure at different infection stages of the plant. In the duplex, nested-PCR assays, the predicted PCR products were clearly visible after the first PCR, as well as after nested-PCR, employing root tissues of D- and ND-inoculated but nonsymptomatic plants sampled 7 days after inoculation. This observation agrees with those in previous studies $(14,15)$, and suggests that pathogen DNA seems to have reached a maximum concentration in the infected olive plant at that time.

Diagnosis of Verticillium wilt in olive cannot be based on symptoms alone, and isolation of $V$. dahliae from affected tissues is needed for confirmation (10,31). Isolation of $V$. dahliae from symptomatic olive branches often is inconsistent and may fail $(4,11,34)$. For example, percentage of isolation of $V$. dahlaie from affected olive trees in Israel ranged from 5.9 to $49.0 \%$ across season within the year, and from 19.1 to $27.9 \%$ depending upon the part of the tree canopy sampled (11). A major goal in our study was the use of the improved detection procedure in olive trees naturally infected by $V$. dahliae. Results confirmed that the procedure is valid for detection of $\mathrm{D}$ and ND pathotypes in infected olive trees of different cultivars, age, and growing conditions. The molecular procedure was more consistent, increased the proportion of positive diagnosis compared with conventional isolations, and, more importantly, revealed the infecting pathotypes, whereas isolations did not. Furthermore, although diagnosis by means of isolation requires 7 to 12 days, the molecular diagnosis can be completed in $48 \mathrm{~h}$.

Our results indicated that care should be taken concerning assay of severely affected or necrotic olive twigs for the in planta molecular diagnosis. Although a low concentration of total genomic DNA still can be extracted from those tissues, a high percentage of the DNA samples were not of optimum PCR quality. However, even in those cases, the molecular detection assay using samples of necrotic twigs provided better results than isolation detections. Sampling of nonsymptomatic tissues from a diseased olive is the best use for the in planta molecular detection of D and ND $V$. dahliae, because of the benefits of early detection of latent infections in green tissues in which the pathogen could be biologically active. In previous studies, D and ND $V$. dahliae detection assays of artificially inoculated olive plants resulted in diagnostic PCR bands from root tissues that were clearer than those for stem tissues from the same plants $(14,15)$. In the present study, however, we focused on stems, twigs, and leaves of naturally infected, adult trees in olive orchards because they are readily accessible for tissue sampling. The DNA extraction and pathotype detection results confirmed that those aboveground tissues are valid for rapid diagnosis of D and ND $V$. dahliae. Nevertheless, the results of $V$. dahliae detection in root tissues of artificially infected olive plants indicated that the newly developed procedure also should be of use in the detection of $V$. dahliae pathotypes in roots of naturally infected olive trees. An appropriate sampling procedure for roots of adult trees in the field seems to be the most critical factor for diagnosis.

The diagnostic assays carried out in this study revealed a high frequency of infection by $\mathrm{D} V$. dahliae in olive orchards sampled in southern Spain. This observation agrees with reports alerting growers about the spread of this most virulent $V$. dahliae pathotype from an area of intense cotton cultivation where it was first reported (2) into olive-growing areas in southern Spain (3,13; R. M. Jiménez-Díaz, unpublished data). Moreover, our finding of joint infections by $\mathrm{D}$ and ND $V$. dahliae pathotypes in naturally infected olive trees, which was further demonstrated in young olive plants artificially inoculated with both pathotypes, is the first such report using molecular detection procedures. Schnathorst and Mathre (28) reported on co-inoculation of upland cotton with D and ND $V$. dahliae isolates T-1 and SS-4, respectively, as well as the cross-protection that the mildly virulent ND isolate provided against the virulent $\mathrm{D}$ isolate in artificially inoculated plants and in cotton plants grown in naturally infested field soil. However, no evidence of the coexistence of both isolates in the same infected plant was presented in that study (28). In the present study, we root-dip inoculated own-rooted olive plants to compensate for the higher colonization ability of olive plants shown by D isolates compared with ND isolates $(24,25)$. Assays using root tissues of plants inoculated with both $\mathrm{D}$ and ND isolates yielded the predicted PCR markers of D and ND $V$. dahliae at 0,7 , and 21 days after inoculation, indicating that penetration and colonization of the roots were achieved by both isolates without apparent interference between the two. However, assays using stem tissues of the same plants yielded only the D marker, suggesting that the D isolate colonized the stem vascular system of an inoculated plant faster than the ND isolate. Detection of the two pathotypes was possible much earlier than the first disease symptoms appeared. In this study, we aimed to demonstrate co-infection of the plant by both D and ND $V$. dahliae but did not intend any approach to verify cross-protection between them. However, becausee co-infection and co-detection were demonstrated, studies on crossprotection by $V$. dahliae pathotypes in olive now may be explored further.

\section{ACKNOWLEDGMENTS}

We thank Agromillora Catalana (Barcelona, Spain) for providing olive plants, A. Valverde and J. L. Trapero for technical assistance, P. Rallo for providing primer pair IAS-oli17f/r, A. Morton for a gift of primers DB19 and DB22, J. Bejarano for providing us with some of the samples of naturally infected olive plants used in this study, and H. F. Rapoport for providing helpful comments and suggestions in reviewing the manuscript.

\section{LITERATURE CITED}

1. Al-Ahmad, M. A., and Mosli, M. N. 1993. Verticillium wilt of olive in Syria. Bull. OEPP/EPPO Bull. 23:521-529.

2. Bejarano-Alcázar, J., Blanco-López, M. A., Melero-Vara, J. M., and Jiménez-Díaz, R. M. 1996. Etiology, importance, and distribution of Verticillium wilt of cotton in southern Spain. Plant Dis. 80:1233-1238.

3. Bejarano-Alcázar, J., Pérez-Artés, E., and Jiménez-Díaz, R. M. 2001. Spread of the defoliating pathotype of Verticillium dahliae to new cotton- and olive-growing areas in Southern Spain. Page 57 in: (Abstr.) Proc. 8th Int.Verticillium Symp. Córdoba, Spain.

4. Blanco-López, M. A., Jiménez-Díaz, R. M., and Caballero, J. M. 1984. Symptomatology, incidence and distribution of Verticillium wilt of olive trees in Andalucia. Phytopathol. Mediterr. 23:1-8.

5. Caballero, J. M., Pérez-Hernández, J., BlancoLópez, M. A., and Jiménez-Díaz, R. M. 1980. Olive, a new host of Verticillium dahliae in Spain. Page 50 in: (Abstr.) Proc. 5th Congr. Mediterr. Phytopathol. Union, Patras, Greece.

6. Carder, J. H., Morton, A., Tabrett, A. M., and Barbara, D. J. 1994. Detection and differentiation by PCR of subspecific groups within two Verticillium species causing vascular wilts in herbaceous hosts. Pages 91-97 in: Modern Assays for Plant Pathogenic Fungi: Identification, Detection and Quantification. A. Schots, F. M. Dewey, and R. Oliver, eds. CAB International, Oxford

7. Dan, H., Ali-Khan, S. T., and Robb, J. 2001 Use of quantitative PCR diagnostics to identify tolerance and resistance to Verticillium dahliae in potato. Plant Dis. 85:700-705.

8. Heinz, R., Lee, S. W., Saparno, A., Nazar, R. N., and Robb, J. 1998. Cyclical systemic colonization in Verticillium-infected tomato. Physiol. Mol. Plant Pathol. 52:385-396.

9. Hu, X., Nazar, R. N., and Robb, J. 1993. Quantification of Verticillium biomass in wilt disease development. Physiol. Mol. Plant Pathol. 42:23-36.

10. Jiménez-Díaz, R. M., Tjamos, E. C., and Cirulli, M. 1998. Verticillium wilt of major tree hosts: olive. Pages 13-16 in: A Compendium of Verticillium Wilt in Trees Species. J. A. Hiemstra and D. C. Harris, eds. Ponsen \& Looijen, Wageningen, the Netherlands.

11. Levin, A. G., Lavee, S., and Tsror (Lahkim), L. 2003. Epidemiology of Verticillium dahliae on olive (cv. Picual) and its effect on yield under saline conditions. Plant Pathol. 52:212218.

Plant Disease / December 20031493 
12. Li, K. N., Rouse, D. I., and German, T. L. 1994. PCR primers that allow intergeneric differentiation of ascomycetes and their application to Verticillium spp. Appl. Environ. Microbiol. 60:4324-4331.

13. López-Escudero, J. 1999. Evaluación de la resistencia de olivo a las variantes patogénicas de Verticillium dahliae y eficacia de la solarización en el control de la Verticilosis. Ph.D. thesis, University of Córdoba, Spain.

14. Mercado-Blanco, J., Rodríguez-Jurado, D., Pérez-Artés, E., and Jiménez-Díaz, R. M. 2001. Detection of the nondefoliating pathotype of Verticillium dahliae in infected olive plants by nested PCR. Plant Pathol. 50:609619.

15. Mercado-Blanco, J., Rodríguez-Jurado, D., Pérez-Artés, E., and Jiménez-Díaz, R. M. 2002. Detection of the defoliating pathotype of Verticillium dahliae in infected olive plants by nested PCR. Eur. J. Plant Pathol. 108:1-13.

16. Morton, A., Carder, J. H., and Barbara, D. J. 1995. Sequences of the internal transcriber spacers of the ribosomal RNA genes and relationships between isolates of Verticillium albo-atrum and V. dahliae. Plant Pathol. 44:183-190.

17. Moukhamedov, R., Hu, X., Nazar, R. N., and Robb, J. 1994. Use of polymerase chain reaction amplified ribosomal intergenic sequences for the diagnosis of Verticillium tricorpus. Phytopathology 84:256-259.

18. Navas-Cortés, J. A., Rodríguez-Jurado, D., Trapero-Casas, J. L., Landa, B. B., MercadoBlanco, J., Pérez-Artés, E., and Jiménez-Díaz, R. M. 2001. Spatio-temporal dynamics of Verticillium wilt epidemics in an olive orchard. Page 59 in (Abstr.) Proc. 8th Int. Verticillium Symp. Córdoba, Spain.

19. Nazar, R. N., Hu, X., Schmidt, J., Culham, D., and Robb, J. 1991. Potential use of PCRmediated ribosomal intergenic sequences in the detection and differentiation of Verticillium wilt pathogens. Physiol. Mol. Plant Pathol. 39:1-11.

20. Pérez-Artés, E., García-Pedrajas, M. D. Bejarano-Alcázar, J., and Jiménez-Díaz, R. M. 2000. Differentiation of cotton-defoliating and -nondefoliating pathotypes Verticillium dahliae by RAPD and specific PCR analyses. Eur. J. Plant Pathol. 106:507-517.

21. Raeder, U., and Broda, P. 1985. Rapid preparation of DNA from filamentous fungi. Lett. Appl. Microbiol. 1:17-20.

22. Rallo, P., Dorado, G., and Martín, A. 2000. Development of simple sequence repeats (SSRs) in olive tree (Olea europaea L.). Theor. Appl. Genet. 101:984-989.

23. Robb, J., Hu, X., Platt, H., and Nazar, R. N. 1994. PCR assay for the detection and quantification of Verticillium species in potato. Pages 83-90 in: Modern Detection Assay for Plant Pathogenic Fungi. M. Dewey, R. Oliver, and A. Schots, eds. CAB International, Oxford.

24. Rodríguez-Jurado, D. 1993. Interacciones huésped-parásito en la Verticilosis del olivo (Olea europaea L.) inducida por Verticillium dahliae Kleb. Ph. D. thesis, University of Córdoba, Spain.

25. Rodríguez-Jurado, D., Blanco-López, M. A., Rapoport, H. F., and Jiménez-Díaz, R. M. 1993. Present status of Verticillium wilt of olive in Andalucia (southern Spain). Bull. OEPP/EPPO Bull. 23:513-516.
26. Sánchez-Hernández, M. E., Ruíz-Dávila, A., Pérez de Algaba, A., Blanco-López, M. A. and Trapero-Casas, A. 1998. Occurrence and etiology of death of young olives trees in southern Spain. Eur. J. Plant Pathol. 104:347357.

27. Schnathorst, W. C., and Mathre, D. E. 1966. Host range and differentiation of a severe form of Verticillium albo-atrum in cotton. Phytopathology 56:1155-1161.

28. Schnathorst, W. C., and Mathre, D. E. 1966 Cross-protection in cotton with strains of Verticillium albo-atrum. Phytopathology 56:1204-1209.

29. Schnathorst, W. C., and Sibbett, G. S. 1971. The relation of strains of Verticillium albo atrum to severity of Verticillium wilt in Gossypium hirsutum and Olea europaea in California. Plant Dis. Rep. 9:780-782.

30. Talboys, P. W. 1960. A culture medium aiding the identification of Verticillium albo-atrum and V. dahliae. Plant Pathol. 9:57-58.

31. Termorshuizen, A. J. 1998. Technical aspects: disease diagnosis and identification of the pathogen. Page 41 in: A Compendium of Verticillium Wilt in Trees Species. J. A. Hiemstra and D. C. Harris, eds. Ponsen \& Looijen, Wageningen, the Netherlands.

32. Thanassoulopoulos, C. C., Biris, D. A., and Tjamos, E. C. 1979. Survey of Verticillium wilt of olive trees in Greece. Plant Dis. Rep. 63:936-940.

33. Tjamos, E. C. 1993. Prospects and strategies in controlling Verticillium wilt of olive. Bull. OEPP/EPPO Bull. 23:505-512.

34. Tosi, L., and Zazzerini, A. 1998. Investigation on the epidemiology of Verticillium wilt in central Italy. Olivae 71:50-55 